IRSH 59 (20I4), Special Issue, pp. I 85-209 doi:I0.10I7/S00208590I4000339 (C) 2014 Internationaal Instituut voor Sociale Geschiedenis

\title{
Motor Transportation, Trade Unionism, and the Culture of Work in Colonial Ghana
}

\author{
JENNIFER HART \\ Department of History, Wayne State University \\ 3094 FAB, 656 W. Kirby, Detroit, MI 48202, USA \\ E-mail: Jennifer.hart4@wayne.edu
}

\begin{abstract}
The emergence of drivers' unions in the I920s and I930s highlights the wide range of strategies for social and economic organization available to workers in the Gold Coast. Particularly among workers who operated outside the conventional categories of the colonial economy, unions provided only one of many models for labor organization. This article argues that self-employed drivers appropriated unions and an international discourse of labor organization in the early twentieth century in order to best represent their interests to the colonial government. However, their understanding of the function and organization of unions reflected a much broader repertoire of social and economic organizing practices. Rather than representing any exceptional form of labor organization, drivers highlight the circulation of multiple ideas surrounding labor organization in the early decades of the twentieth century, which informed the ways in which Africans engaged in the wage labor economy and implicitly challenged British colonial assumptions about labor, authority, and control.
\end{abstract}

In 1935, experienced drivers and local political and religious officials gathered under palm trees along the beach in La, an eastern suburb of Accra, capital of the Gold Coast, to inaugurate a new drivers' union. La was widely recognized by both colonial officials and African workers as the colony's preeminent center for driver training and practice. The new members designated a chief driver and a linguist, who were to facilitate the work of the union, and the new officers swore an oath of office on a steering wheel. ${ }^{\mathrm{I}}$

In organizing themselves into a union, La drivers were participating in a broader culture of associational life among entrepreneurial African drivers

I. Gene Quarshie (Chairman), P. Ashai Ollennu (Vice-Chairman), and Simon Djetey Abe (Secretary), La Drivers' Union Officers Group, La, Accra, 23 March 2009, interview by the author. 
in the I930s - one that drew both on the international language of trade unionism and indigenous cultures of labor organization. The material and symbolic culture of chieftaincy ("chief driver", "linguist", for example) was the most visible and superficial example of the extent to which local practices of work and authority influenced an emerging union culture among drivers. The organizing strategies and practices of drivers formed the framework of a "mobility system" rooted in cultures of masculinity, respectability, apprenticeship, entrepreneurialism, and state regulation in the region. ${ }^{2}$ By adapting these indigenous practices to emerging systems of trade unionism, drivers in $\mathrm{La}$ and throughout the colony sought to organize their work to provide better service for passengers and represent their interests to the state.

The culture of drivers' unions and work lives differed substantially from the unionized railway workers, dockworkers, civil service employees, and other waged laborers who followed more conventional models of union organization and who participated in forms of work defined by British colonial capitalism. By transporting goods for trade, drivers were central to systems of exchange and accumulation in the colony, facilitating the expansion of a colonial capitalist economy. While drivers derived socioeconomic benefits from this system, which they used to establish lives of masculine respectability and prestige in colonial society, they did so with significantly greater autonomy than other African workers in the colonial economy. Most drivers were self-employed, owning their own vehicles and solely controlling the profits from their business. In transporting both goods and people throughout the colony, drivers, as indigenous entrepreneurs, facilitated the connections and mobility of overlapping entrepreneurial networks. Peasant farmers, market traders, and drivers worked together to reshape the colonial economy and defined a new future for their country, not in political terms, but through the language and practices of economic self-interest. Likewise, drivers, who were largely self-employed, interpreted the function and structure of unions in light of indigenous practices of the organization of labor and the expression and exercise of authority.

The unionization of drivers reflected the culmination of nearly three decades of African attempts to claim control of motor transportation from the colonial authorities and regulate access to it on their own terms. Africans appropriated motor vehicles in large numbers soon after their introduction into the Gold Coast Colony in the first decade of the twentieth century. By the I930s, motor transportation was well established as an important commercial activity among Africans in the southern Gold Coast, providing economic opportunities for young African men outside colonial pathways of education and respectability and enabling Africans to define their own version of modern mobility. Drivers were entrepreneurs, 
who saved their profits to purchase their own vehicles and attain economic autonomy. By transporting both goods and people and connecting rural villages with urban markets, drivers provided an essential public service, which facilitated the continued growth of the Gold Coast market economy and the prosperity of traders and cocoa farmers throughout the southern half of the colony. At the same time, it challenged colonial attempts to control African mobility and economic activity.

By the 1930s, it became clear to colonial officials that African motor transportation could no longer be ignored. After decades of neglect in road construction and maintenance and limited investment in motor transport regulation and infrastructure, the British colonial state implemented a new and extensive set of motor traffic regulations in 1934, which sought to control motor transportation more directly, defining both driving practice as well as "the type of man who could be a driver". In response, drivers organized themselves into countless local professional associations, such as the Bekwai Transport Union, and national umbrella organizations like the Gold Coast Motor Union. These organizations quickly engaged in strikes, as well as petition-writing campaigns to the colonial Governor, seeking to limit the effects of the shifting parameters of government regulation on drivers' livelihoods.

In forming associations and unions, self-employed drivers appropriated the language and practices of British trade unionism rooted in the experiences of the British working class - waged workers in the employ of industrial capital. Based on such a definition of trade unionism, scholars of African labor unions in the decades immediately following independence criticized these organizing efforts, which in their view, focused too much on either state employees and or the self-employed. ${ }^{3}$ The centralized nature of colonial capitalism - in which both labor and resources were concentrated in the extractive structures of the colonial state - limited the growth of African industry and independent waged labor. Thus, unionized Africans directed their activities towards the state, which regulated the conditions of work for both state employees and self-employed groups throughout the colony.

Dockworkers and railway workers, in particular, used their unions to speak out against the abuses of colonial rule and the conditions of life for the African working class in a number of colonies. ${ }^{4}$ In part, the success of

3. See, for example, R.B. Davison, "Labor Relations in Ghana", Annals of the American Academy of Political and Social Science, 310 (March 1957), pp. I33-14I; Jon Kraus, "African Trade Unions: Progress or Poverty?”, African Studies Review, 19:3 (December 1976), pp. 95-108; Charles A. Orr, "Trade Unionism in Colonial Africa", The Journal of Modern African Studies, 4 (1966), pp. 65-8I.

4. Frederick Cooper, Decolonization and African Society: The Labor Question in French and British Africa (Cambridge, 1996); idem, On the African Waterfront: Urban Disorder and the 
dockworkers and railway workers' unions lay in their conventionality; these unions mobilized state employees and waged laborers who protested the conditions of their employment and engaged in collective bargaining. However, trade unionism on the continent extended far beyond the limits of the continent's relatively small waged labor force, incorporating entrepreneurs, traders, farmers, and drivers, among others, in a widespread labor movement, which had widely varying political motivations and organizing strategies. The expansiveness and inclusiveness of African trade unionism often drew criticisms from early observers, who argued that the appropriation of the union model by unconventional sectors of the labor force reflected the degree to which Africans failed to understand the meaning and function of unions. ${ }^{5}$

African trade unions were indeed different from their British models. However, trade unionism did not emerge (or arrive) in a vacuum. British trade unionists sent to the Gold Coast met a complex set of societies with their own structures, rules, and logics of labor organization. As scholars like Fred Cooper and Keletso Atkins have demonstrated elsewhere on the continent, African workers often interpreted European conditions and expectations of labor in light of indigenous cultures of work. ${ }^{6}$ In taking these indigenous cultures of work seriously, we must also consider "what African workers brought to the workplace". 7 Much like the ways in which Africans appropriated and adapted Western structures to make them locally meaningful in other aspects of colonial society, culture, and economy, unions did not merely appear as an importation but rather emerged from and in collaboration with local cultures and practices of work. Both unions and indigenous forms of labor organization and economic accumulation were transformed in the process.

This article explores the meaning and significance of early union formation among self-employed African drivers in light of these scholarly

Transformation of Work in Colonial Mombasa (New Haven, CT, 1987); Richard Jeffries, Class, Power and Ideology in Ghana: The Railwaymen of Sekondi (Cambridge, 2009); Lisa Lindsay, Working with Gender: Wage Labor and Social Change in Southwestern Nigeria (Portsmouth, $\mathrm{NH}, 2003)$.

5. Roger Scott, “Are Trade Unions Still Necessary in Africa?", Transition 33 (OctoberNovember 1967), pp. 27-3 I; Lester N. Trachtman, "The Labor Movement of Ghana: A Study in Political Unionism", Economic Development and Cultural Change, Io (1962), pp. I83-200.

6. Cooper, On the African Waterfront; idem, From Slaves to Squatters: Plantation Labor and Agriculture in Zanzibar and Coastal Kenya, I890-1925 (New Haven, CT, 1981); Keletso Atkins, The Moon is Dead! Give Us Our Money! The Cultural Origins of an African Work Ethic, Natal, South Africa, I843-1900 (Portsmouth, NH, I993).

7. Ibrahim Abdullah, "Rethinking African Labor and Working-Class History: The Artisan Origins of the Sierra Leonean Working Class", Social History, 23 (1998), pp. 80-96, 80; Frederick Cooper, "Work, Class and Empire: An African Historian's Retrospective on E.P. Thompson", Social History, 20 (1995), pp. $235-24$ I, 236. 
discourses about "indigenous cultures of work" and the emergence of pre-colonial working-class consciousness among artisans and other tradespeople along the West African littoral. ${ }^{8}$ In particular, I argue that the emergence of drivers' unions in the I920s and I930s, and the structure and function of those unions, highlight the wide range of strategies for social and economic organization available to workers in the Gold Coast. Particularly among workers, such as drivers, who operated outside the conventional categories of the colonial economy (wage laborer, subsistence farmer, slave, for instance), unions provided only one of many models for labor organization. Drivers also strategically drew on indigenous cultures of entrepreneurialism, apprenticeship, and chieftaincy in order to organize their labor and secure respect, authority, and legitimacy, among both African communities and the colonial state. As a result, drivers' unions that formed in the I930s looked far different from both British models and indigenous practices of labor organization. These new unions facilitated the continued economic autonomy of drivers in the midst of increasing efforts at state regulation.

In order to understand drivers' practices of labor organization, it is necessary to understand the broader culture and economy of which they were a part. This article situates the emergence of drivers' unions within the various coexisting systems of labor organization in the Gold Coast, paying particular attention to the role of entrepreneurialism, apprenticeship, and the state/chieftaincy in local economies of production and trade. Drivers drew on these indigenous cultures and practices of work in order to guarantee their legitimacy and authority among local populations. When the state required union formation and registration in the I930s as a condition of negotiation, drivers adapted these local practices within a union framework. In the process, they reshaped expectations and understandings of both local economies and union organization.

\section{MULTIPLE LANGUAGES OF LABOR}

In the Gold Coast, African engagement with the British colonial cash economy as either waged laborers or entrepreneurs in the nineteenth and twentieth centuries drew on a much longer history of economic activity at local, regional, and trans-continental levels. Similar to the ways in which laborers in southern and eastern Africa brought indigenous understandings of work to the farms, docks, and railways of these British settler colonies, African understandings of labor in the Gold Coast were also rooted in long-standing indigenous cultures of work. In particular, indigenous

8. Abdullah, "Rethinking African Labor and Working-Class History"; Peter Gutkind, "The Canoemen of the Gold Coast (Ghana): A Survey and an Exploration in Precolonial African Labour History", Cahiers d'Etudes Africaines, 29 (1989), pp. 339-376. 
political leaders controlled access to land and resources within local economies that were dominated by entrepreneurs and organized through systems of apprenticeship. Through these systems of labor organization, both leaders and the general population sought to balance the regulation of resources and infrastructure with the values of economic autonomy and entrepreneurialism.

Local labor practices and economic institutions were part of regional and transnational networks of trade and exchange, which connected Africans throughout the western part of the continent and spurred local economic production. Local leaders who sought to profit from these trade networks engaged in often large-scale mobilization and organization of labor for agriculture, trade, mining, and other pursuits. ${ }^{9}$ Labor organization for both local production needs and long-distance trade throughout the southern Gold Coast inevitably varied among economic sectors and ethnic groups. Among politically centralized Akan communities in the forests of the interior, agriculture and gold mining tended to be more directly controlled by chiefs, who mobilized the labor of villagers to tend their own farms or work in mines and who controlled access to land and at least a portion of the produce of individual effort in the form of tribute and/or taxes. However, much of the profits from agricultural produce like palm oil and cocoa remained with entrepreneurial cash-crop farmers.

When cocoa production surpassed palm oil as the colony's major export in the nineteenth century, cocoa farmers also had to mobilize and control labor to work their rapidly expanding farms, often accumulating multiple wives and children to provide farm labor and employing local youth and women to tend farms and help with the harvest and transport. ${ }^{1 \circ}$ While occupations were gendered, the boundaries of that gendered division of labor had shifted by the early twentieth century with the introduction and expansion of cocoa farming. As men left the markets to set up cocoa farms, women took their place, utilizing new technologies of mobility to dominate both local and long-distance trade throughout the region. ${ }^{\text {II }}$ Young men and women learned trades and skills through formal or informal apprenticeships, assisting (often related) adults in work on farms, at mines, at the market, or in the water. Among less centralized societies

9. As Beverly Grier argues, in pre-colonial societies where land was abundant, but population densities were relatively low, "the struggle to control labor power was at the heart of social and political organization"; Beverly Grier, "Pawns, Porters, and Petty Traders: Women in the Transition to Cash Crop Agriculture in Colonial Ghana", Signs, I7 (I992), pp. 304-328, 307. Io. Ibid.

I I. Gracia Clark, Onions Are My Husband: Survival and Accumulation by West African Market Women (Chicago, IL, I995); Claire Robertson, Sharing the Same Bowl: A Socioeconomic History of Women and Class in Accra, Ghana (Bloomington, IN, I984); Jean Allman and Victoria Tashjian, I Will Not Eat Stone: A Women's History of Colonial Asante (Portsmouth, NH, 2000); Stephan Miescher, Making Men in Ghana (Bloomington, IN, 2005). 
like the $\mathrm{Ga}$, commercial activities such as fishing and the trade in smoked fish were often also organized at the household level, as both men and women collected, processed, and traded the coastal commodity. ${ }^{\mathrm{I}}$

Across all of these societies, however, the state played a central role in regulating access to resources and dictating the conditions of possibility for various forms of work. The state often maintained a much tighter control on the activities of traders, who generated significant wealth. In Asante, for example, individuals had to obtain the permission of the Asantehene (King of the Asante) in order to travel for the purposes of trade. Although Asante traders were, to a large extent, entrepreneurs, they represented the Asante state in their trading activities. ${ }^{13}$ Other groups of "artisans", including weavers, blacksmiths, goldsmiths, and musicians, were often employed directly by the royal court, which protected access to privileged royal symbols and technical skills passed down through formal apprenticeships. ${ }^{\text {I4 }}$

Despite the importance of the state in regulating economic conditions and possibilities, however, Kwame Arhin argues that even in politically centralized states like the Asante, "[t]here were [...] no landlords and tenants, owners of capital and labourers. There were husbands and wives as owners of farms, master craftsmen, and long-distance traders, and their nnipa (sing. onipa), lit. 'human beings', but in this context dependants, who did not belong to socially or politically opposed groups." " For some members of Asante communities, these small-scale economic activities enabled them to take their places within a relatively hierarchical Asante state and society. However, for others, the relative autonomy of the Asante economy made it possible to establish themselves as "indigenous entrepreneurs". ${ }^{16}$

These "indigenous entrepreneurs" played a significant role in shaping the social, political, and economic possibilities of Asante society - a significance acknowledged by their distinguished status as obirempon (Asante Twi: "big men"). As Dumett explains through his analysis of African merchants, the category of "entrepreneur" should not be casually applied to every small-scale economic agent. However, "[a]n entrepreneur certainly does not have to be an industrialist; he can be a trader, farmer, or

I2. Robertson, Sharing the Same Bowl.

13. There are, of course, exceptions to this general statement, as illustrated by Kwame Arhin, "Trade, Accumulation and the State in Asante in the Nineteenth Century", Africa, 60 (I990), pp. 524-537.

I4. J.H. Kwabena Nketia, Drumming in Akan Communities of Ghana (London, 1963).

I 5. Kwame Arhin, "Rank and Class among the Asante and Fante in the Nineteenth Century", Africa, 53 (1983), p. 5 .

16. Raymond Dumett, "Tropical Forests and West African Enterprise: The Early History of the Ghana Timber Trade”, African Economic History, 29 (2001), pp. 79-1 16, 92. 
skilled craftsman." Entrepreneurs are "change agents" who organize production and distribution in novel ways. ${ }^{17}$ Entrepreneurialism does not, however, negate the importance of the state in organizing and regulating economic activity and access to capital and resources. Even in "port cities" 8 at the edge of the Sahara and on the coast, where a professional class of traders operated for personal profit rather than as direct agents of the state, local leaders, colonial officials and European merchant houses often heavily mediated access to both goods and transport. ${ }^{19}$

While indigenous understandings of work and economy profoundly shaped early interactions with Europeans, the increase in European trade and the introduction of the cash economy beginning in the fifteenth century also introduced new forms and understandings of work and economic accumulation. Early coastal trading interactions spawned a number of new occupational categories or expanded existing occupations, including but not limited to traders, canoe men, and carriers. Africans who engaged in the earliest forms of casual waged labor at the coast organized for the purposes of bargaining for better pay and working conditions. Their importance as a labor force was crucial to the functioning of the colonial economy, adding extra weight to their demands in interactions with early European traders and colonial officials in the eighteenth and early nineteenth centuries. Canoe men, for example, who, in large part due to their autonomy as casual workers, could withdraw their labor in protest over conditions and pay, regularly halted economic activity at the coast to the detriment of European commercial interests. ${ }^{20}$ However, these casual workers also largely followed indigenous patterns of labor organization, rooted in the efforts of individual entrepreneurs and their apprentices, operating within limitations imposed by the colonial state and the demands of merchants operating at coastal ports.

\section{CULTURES OF WORK AND THE MOBILITY OF MOTOR TRANSPORTATION}

Early economic interactions between Europeans and Africans laid the foundation for a colonial economy in the nineteenth and twentieth centuries that was heavily dependent on the economic contributions of African entrepreneurs in agriculture, mining, trade, and transportation. While some

17. Idem, "African Merchants of the Gold Coast, I860-1905: Dynamics of Indigenous Entrepreneurship", Comparative Studies in Society and History, 25 (1983), pp. 661-693, 662-664.

18. Ghislaine Lydon, On Trans-Saharan Trails: Islamic Law, Trade Networks, and CrossCultural Exchange in Nineteenth Century Western Africa (Cambridge, 2012).

I9. Dumett, "African Merchants of the Gold Coast".

20. Gutkind, "Canoemen of the Gold Coast". 
of these sectors experienced significant transformation in response to new technologies and resources, both colonial officials' and African workers' expectations of the colony's economic future were rooted in indigenous economic practices and networks. African men took up work as motor transport drivers in this context of broader economic activity in the Gold Coast. In particular, the expansion of motor transportation and driving as an occupational category grew directly out of the activities of cocoa farmers, who viewed motor vehicles as a wise investment in the I920s and 1930 s. $^{21}$

By the cocoa boom of the 1920 , farmers, traders, and a new category of African transport owners and drivers began to construct their own networks and means of transportation, often outside colonial government control and contrary to government interests. Motor transportation not only provided a new form of entrepreneurship that was accessible to Africans in the Gold Coast, it also allowed farmers and traders to assert greater control over the production and trade in primary commodities such as cocoa. ${ }^{22}$ Parallel to this increasing demand for vehicles, after World War I the Gold Coast was also home to a much larger population of drivers. While deployed in East Africa during World War I, half of the Mechanical Transport Unit of the Gold Coast Regiment received training as drivers. Many of those who returned found work as drivers in the booming cocoa industry of the i 920 s. Soon drivers began establishing independent services, purchasing vehicles and hiring out their services to traders, farmers, and other travellers. By 1930, 4,987 vehicles were licensed in the Gold Coast Colony. ${ }^{23}$

Emerging systems of training for drivers also reflected both the continuities and broader transformations in the colonial economy. Much like the apprenticeship systems that had traditionally served to train young men and women in adult occupations, drivers developed systems of

21. As Polly Hill argues, lorry ownership and operation were some of the only "common forms of economic enterprise which sprang directly from cocoa farming". By the beginning of what Hill characterizes as the "lorry age" in 1918, "it became the fashion, for those who could afford it, to travel by lorry for most of the way" during their migrations as cocoa farmers; Polly Hill, The Migrant Cocoa-Farmers of Southern Ghana: A Study in Rural Capitalism (London, 1998), pp. 190, 234.

22. The lorry is so important to the rise of cocoa that Polly Hill uses the advent of the lorry to establish periodization in her study of migrant Akwapim cocoa farmers. She argues that I9I 8 marked the end of the pre-lorry age, which corresponds with evidence of an increase in the number of drivers post-World-War-I as well as the increased investment in road building as a result of Guggisberg's Ten Year Development Plan. See Hill, The Migrant Cocoa Farmers of Southern Ghana, p. 6.

23. Public Records and Archives Administration Department, National Archives of Ghana, Accra, Ghana [hereafter, PRAAD-NAG], Colonial Secretary's Office [hereafter, CSO] i 4/2/ 329 Road Transportation Board - Formation of. 


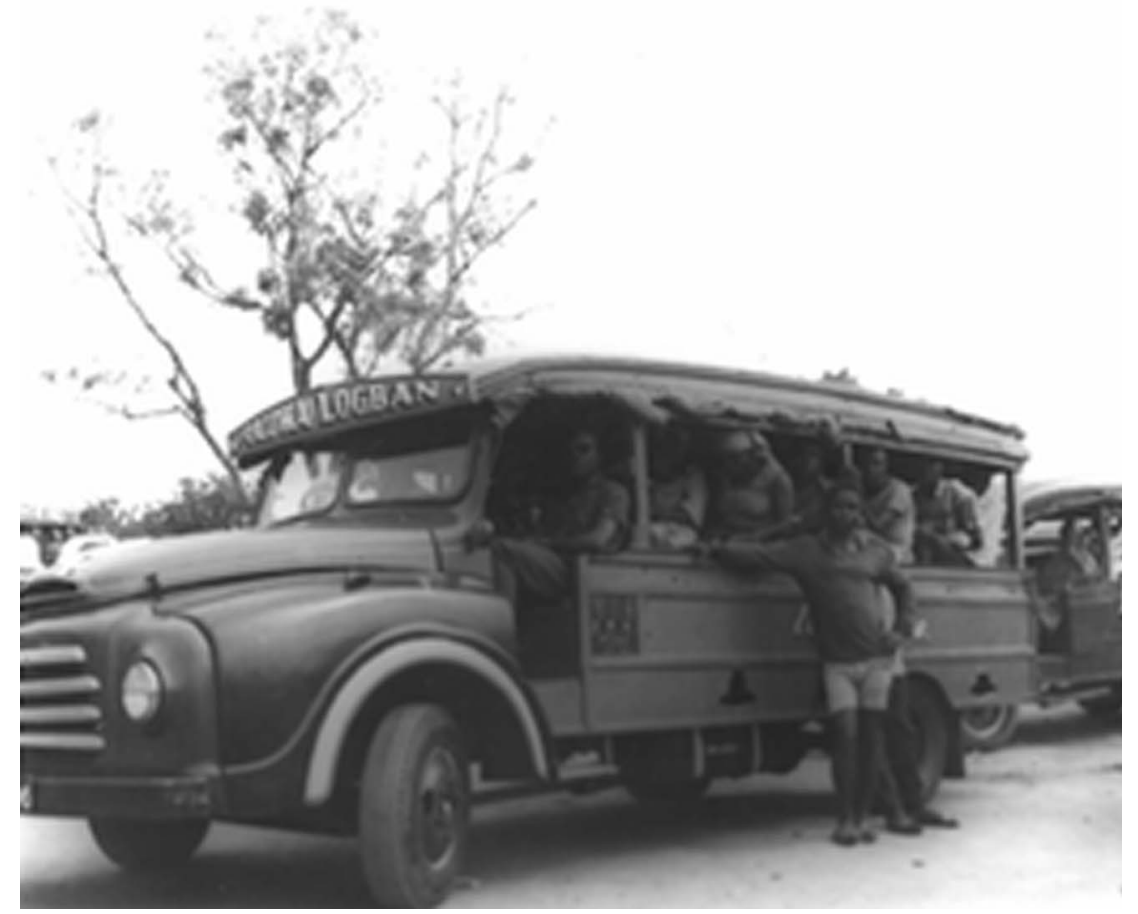

Figure I. "Mammy Trucks", i 8 July i 968 . A driver's mate stands beside a mammy truck loaded with passengers in Accra. While the photograph dates from the I960s, this type of vehicle had been in use since the I930s, with the structure of the vehicle generally unchanged from the earliest forms of mass-produced vehicles. Both drivers and passengers referred to these vehicles as "Bedfords", after the British truck manufacturer, which dominated early imports. "Bedford" came to represent a category of vehicle, consisting of an imported metal chassis and a locally constructed wooden body. Drivers and mates could easily change vehicles from passenger to goods transport depending on the nature of their trips.

Photograph: George A. Alhassan. Copyright: Ministry of Information (Ghana), Information Services Photographic Archive, ref no. R/R/9175/13. Used with permission.

training through which apprentices would learn the craft and skill of driving work. These apprentice drivers, or mates, entered into relationships that were similar in many ways to indigenous apprenticeships among skilled artisans. Families often presented masters with drinks (beer, gin, and/or akpeteshie), ${ }^{24}$ cigarettes, and cash in payment for their services, which then indentured the young man to the master as his "mate".

24. Akpeteshie is a type of local gin distilled from palm wine. For more information on the history of akpeteshie, see Emmanuel Akyeampong, "What's in a Drink? Class Struggle, Popular Culture and the Politics of Akpeteshie (Local Gin) in Ghana 1930-67", Journal of African History, 37 (1996), pp. 2 I 5-236. 
Being a mate entailed a number of responsibilities, including the basic maintenance and cleanliness of the vehicle (washing the vehicle, checking vehicle fluid levels, for instance), loading and unloading goods, obtaining passengers (i.e. fighting for passengers) in lorry parks, aiding the master in repairing the vehicle, and other domestic responsibilities in the master's household, including ironing, pounding $f u f u,{ }^{25}$ sweeping, and cleaning. In exchange, mates were often given lodging and food, as well as driver training. Driving apprenticeships were also highly gendered, and driving was considered inherently masculine work that required both physical and mental strength to survive the difficulties and dangers of the road.

For those who grew up in communities like La (a suburb east of Accra), which was closely associated with driving in the first decades of the twentieth century and where driving had been established as a dominant occupation since at least the I9Ios, young men saw driving as a desirable and respected family tradition. As a result, entering into an apprenticeship as a driver's mate seemed like a natural extension of local economies and cultures of work. For drivers like J.F. Ocantey, growing up in a household and community of drivers exposed him to the profession and its skills early and the sons of drivers often followed their fathers, uncles, or elder brothers into the profession. Driving, for Ocantey, was a "hobby" from an early age, and early exposure gained through helping relatives inculcated a passion for driving work and provided him with early training. ${ }^{26}$

When Ocantey later entered into an apprenticeship under master driver N.V. Labadi he fully understood the profession in both its technical and social dimensions, and he benefited from the support and encouragement of family members. As Ocantey describes, for those who grew up in La, driving was "in their blood":

For the driving, they born us in the driving work because where we were born from, driving is the work that most of the people have been doing. That is the reason why - our area here in $\mathrm{La}$, we like driving. You should understand that La people are the people who brought driving into the system because the first driver in Ghana here, he come from La. Before it spread around the whole of Ghana - it's La it started from. The thing is, this man sitting here - his father is a driver, so he was born in the driving work because his father is driving, and I myself too, my senior brother was a driver so any time he always bring cars to the house so even if he's not there and I enter the car, once you spark the car and you accelerate it, the car will move. So that is what we've been doing - once our fathers or brothers brought the cars to the house for us to wash, we would be

25. Fufu is a local food staple, most commonly made by pounding cassava and plantain (though also sometimes with yam). Fufu is pounded with a large mortar and pestle and often requires two people - one to pound and one to turn the product.

26. Ibrahim Ato, Anum Sowah, Yii O. Yem, J.F. Ocantey, La Drivers' Union Group Interview, Accra, 26 March 2009, interview by the author. 
sparking the cars and that brought our interest, so that make us to have the interest of the driving work. ${ }^{27}$

For those young men without any family connections to the driving profession or who did not come from a community of drivers, driving work was appealing precisely because of its novelty. Young boys like Coblah Nimo who lived in farming and fishing communities often stopped work to watch as "mammy" trucks and other motor vehicles passed. Mammy trucks, which were named for their most frequent passengers (market women, aka "mammies"), were hybrid vehicles, consisting of an imported metal engine and chassis and a locally constructed and painted wooden body. In the first half of the twentieth century, mammy trucks dominated Gold Coast roads, as drivers carried market women into the interior to purchase produce from farms and regional markets or to transport the produce of wealthy cocoa farmers to coastal ports. Traveling past villages and farms, these vehicles captured the attention of many young boys who were working or playing along the roadside. The fascination with cars extended into play, as boys pretended to be drivers, improvising imagined vehicles and "blowing" horns (porpor) as they traveled back and forth to collect water. ${ }^{28}$ When motor vehicles arrived in their villages, children swarmed around them, looking at themselves in the reflection of the metallic chassis and sitting behind the steering wheels pretending to drive. ${ }^{29}$ Many of those who ultimately became drivers described themselves as completely occupied - if not spellbound - by the vehicle and its driver, and saw driving as a calling or vocation that was "in their heart".

However, for boys in rural areas outside driving communities, the pursuit of driving and the experience of apprenticeship as mates marked a distinctly different occupational path from that of their families. ${ }^{30}$ While many parents ultimately sought out connections through extended family to secure apprenticeships for their sons with respected masters, such training often implied relocation - as mates looked for masters in major cities like Accra, where most drivers were based. For these young men and their families, embracing motor transportation as an occupation and engaging in the apprenticeship system marked a significant diversion from local economies and communities, even as their mobility connected these communities to larger markets and systems of economic exchange. Regardless of their background, however, most young mates received the same training in the technical and social skills of driving work. Saving

29. Anonymous Circle Odawna Driver, Accra, 27 August 2009, interview by the author.

30. Ibrahim Ato, Anum Sowah, Yii O. Yem, J.F. Ocantey, La Drivers' Union Group Interview, Accra, 26 March 2009, interview by the author; Abraham Tagoe, Teshie Linguist, Accra, 5 August 2009, interview by the author. 
money through their work as mates and apprentices, young drivers sought to purchase their own vehicles. Validated by both their masters and the licensing test of the colonial state, young drivers entered the professional world of commercial motor transportation as professional, skilled workers and self-employed entrepreneurs, ready to take advantage of the possibilities for accumulation and respectability that driving promised.

By the I930s, these drivers had established themselves as an important commercial industry, undermining the profits of the state-owned railways and dominating the colony's transport industry. Their popularity reflected the degree to which drivers successfully used the emerging technology of the motor vehicle to provide essential services for African economic agents. Unlike railways, which represented British understanding of mobility and economic productivity, motor transportation corresponded more directly with the needs and values of African entrepreneurs, who sought to minimize cost and maximize profit for their produce or trade goods. Drivers connected rural African farmers with urban coastal markets and provided a crucial link that transcended the divides between rural and urban life, which characterized the infrastructure, bureaucracy, and economy of indirect rule. In providing a new way for Africans to express the needs and desires of mobility and profitability, drivers acted as the "change agents", altering the economic and social landscape for both Africans and Europeans in the Gold Coast at the same time as they drew on indigenous cultures of occupational training and commerce.

\section{REGULATING AND ORGANIZING DRIVERS IN THE BRITISH GOLD COAST}

The consolidation of motor transport as a legitimate commercial activity in the Gold Coast was paralleled by a professionalization of driving and drivers as both government officials and drivers themselves created rules and codes of conduct that regulated the industry and its participants. Drivers and government officials embraced the apprenticeship system as an important means by which young men became professionalized as drivers. Viewed through the lens of indirect rule, state appropriation of the indigenous apprenticeship system facilitated a more effective means of vocational training than colonial schools or vocational institutions in a wide range of occupations without additional state investment in educational infrastructure or occupational training. ${ }^{3 \mathrm{I}}$ However, government disengagement with driver training was also part of a larger dismissal of the emerging motor transport industry throughout the first decades of the twentieth century. 
Having invested heavily in the railways as the colony's new means of evacuating the produce of farms in the interior for export at coastal ports in the late nineteenth and early twentieth centuries, colonial officials at this time sought to discourage the growth of motor transportation, refusing to build roads or maintain infrastructure, as part of an attempt to address the empire-wide problem that Colonial Secretary Lord Passfield termed "road vs. rail competition". ${ }^{2}$ When these initial efforts failed to deter African drivers and passengers, colonial officials instituted a system of road breaks and passes that would limit African access to roads and undermine the profitability and ease of motor transportation..$^{33}$

Government lack of interest in encouraging the growth of motor transportation and their attempts to protect their investment in the railway as the colony's primary form of transportation created opportunities for investment and entrepreneurialism for Africans who appropriated new technologies to meet the needs of an increasingly mobile African public with disposable income. If vehicles numbered only I 6 in 1908 , by I 932 there were 4,I4I commercial motor vehicles and I,6I 8 private cars and taxis registered on the Gold Coast. By the end of the I930s, there were over 5,50I commercial vehicles and 2,076 private cars and taxis. ${ }^{34}$

The growth in car ownership and commercial motor transport practice in spite of government attempts to suppress it meant that, instead of shaping the industry through regulation from the beginning, colonial officials had to impose regulations on an industry that was already wellestablished in its own system of occupational practice. In implementing these regulations, colonial officials were motivated by a complex set of goals that reflected the often contradictory ideals of the colonial project. On the one hand, transportation was central to the profitability of the colonial economy, which colonial officials sought to control through the railways. The growth of motor transportation undermined government control over the movement of people and goods in the colony and threatened state profits from the railways, even as it facilitated trade. On the other hand, the popularity and affordability of motor vehicles brought increasing numbers of vehicles to Gold Coast roads, and advances in technology enabled drivers to carry heavier loads at higher speeds than ever before.

32. The National Archives (United Kingdom) [hereafter, TNA]: PRO CO 323/1 $339 / 8$ Transport - Road and Rail Competition, I935; PRAAD-NAG (Accra) CSO I 4/2/23 1930-1 93 I Road and Rail Competition; TNA: PRO CO 937/49/4 1947 Transport - Road and Rail Competition; TNA: PRO CO 323/1393/3 1936 Transport - Road and Rail Competition; TNA: PRO CO 262/652 Sierra Leone Railway-road competition, Gold Coast Model 1936.

33. PRAAD-NAG (Accra) CSO I4/2/I 50 I929-I947 Road Policy.

34. PRAAD-NAG (Accra) CSO i 5/I/65 I $932-1940$ Registration Statistics of Motor Vehicles Abroad - Forms for. 


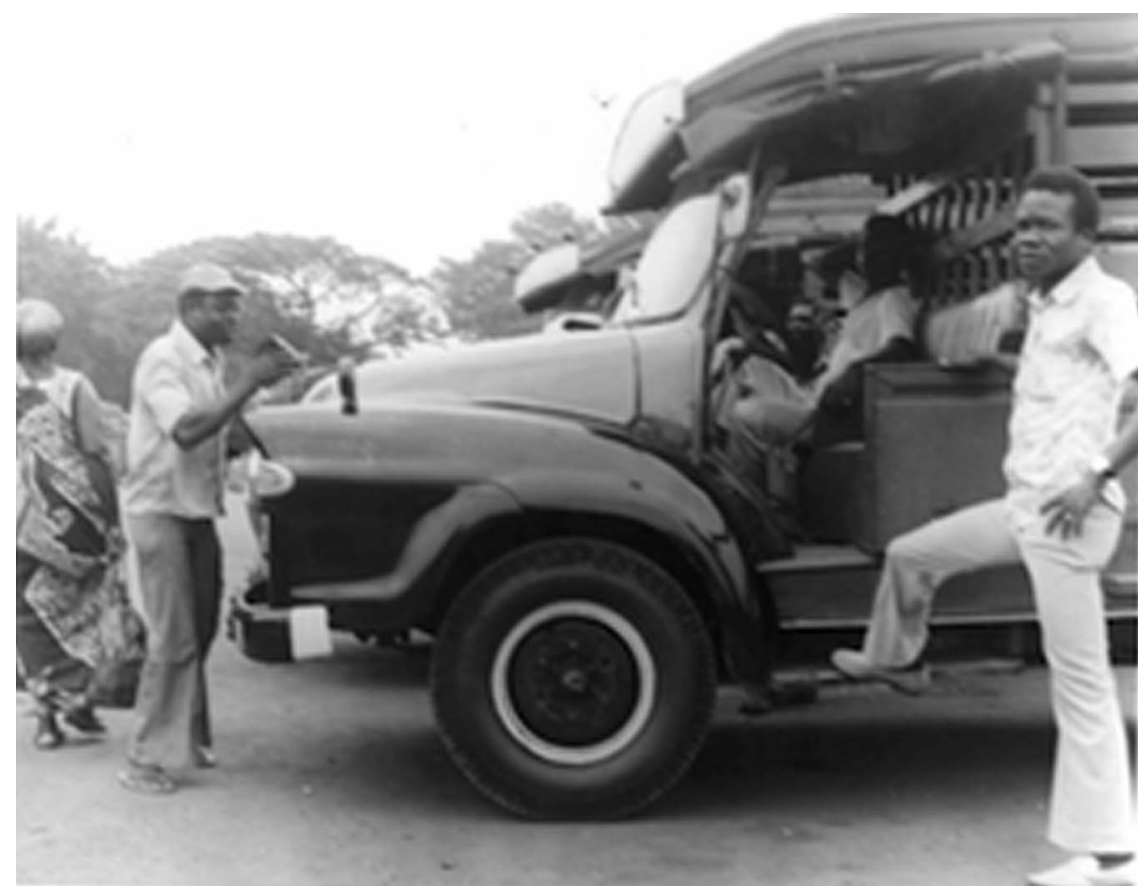

Figure 2. "The driver, Murphy, waits patiently for his turn while his mate cleans the bonnet". There was no date attached to this photograph recorded in the archival record. Apprenticeship systems trained prospective young drivers or "mates", pairing them with master drivers. Mates performed basic maintenance on the vehicles, and often also performed chores for their masters. By observing the work of their masters, mates gradually gained the knowledge and skills required for driving work. As this image and its caption also highlight, drivers' work was just as often defined by immobility and waiting for passengers.

From A Day in the Life of a Tro-tro Driver. Photograph: Ben Kwakye. Copyright Ministry of Information (Ghana), Information Services Photographic Archive, ref. no. PS/I877/6. Used with permission.

These changes undoubtedly presented an existential danger of accidents for passengers and pedestrians on and alongside the colony's poorly maintained roads in rural and urban areas. Both African leaders and colonial officials sought to mitigate these dangers in the name of public safety and "public interest", implementing new restrictions on the speed and roadworthiness of vehicles and investing in road construction and improvements. Drivers, however, argued that these new regulations placed an unfair burden on drivers, who sought to mitigate the risk posed by poorly constructed and maintained roads while also maximizing profits. Colonial interest in regulating drivers in the I930s also appeared hypocritical in light of several decades of government disengagement and economic sabotage. 
Government attempts to regulate motor transportation culminated in the 1934 Motor Traffic Ordinance. Government regulations had long mandated the size, weight, and speed of vehicles. However, by requiring drivers to be literate (i.e. be able to read and understand the Motor Traffic Ordinance and to read road signs), undergo physical examinations, and submit certificates of competency, the colonial state increasingly attempted to dictate who could and who could not be a driver. By asserting control over the access to and use of their vehicles and by defining the qualifications necessary to be a driver, the colonial state and its representatives also asserted control over the possibility and prosperity of drivers' work. The colonial government subsidized the price of petrol, as well as essential imported goods like tires and spare parts. Thus, even if drivers owned their own vehicles, the ability to run those vehicles commercially and profitably was highly dependent on the actions of government - both through its institutions (Legislative Assembly, Ministry of Transportation, Ministry of Trade, etc.) and through individual representatives (licensing officers, police officers, etc.).

Increasing state efforts to control drivers and define the conditions of their training, qualifications, and work coincided with the growing professionalization of drivers, who had begun to view themselves as a powerful social and economic force by the I930s. The professionalization of driving as an occupation and socio-economic category was manifested most clearly in the emergence of unions. While drivers' associations had undoubtedly existed prior to 1930, the formation of the Gold Coast Motor Union, the Ashanti Motor Transport Union, the La Drivers' Union, and others in the I930s marked the first large-scale attempts at organizing the multitude of individual (African) owner-operators who comprised the largest proportion of the motor transport industry in the Gold Coast. Dominated by ex-servicemen who had been trained to drive while serving in the Gold Coast Regiment in the I920s, these new unions established rules of personal behavior (how to drive, how to conduct yourself with passengers, how to dress, how to maintain your vehicle, etc.) as well as rules of procedure (training drivers, resolving disputes, punishing bad behavior, organizing in the lorry park, setting fares, interacting with the police, petitioning the government, etc.). ${ }^{35}$

Driver appropriation of the language and structures of unions reflected both the influence of African radical politics and the importance of British trade unionism in interwar colonial governance. Throughout the I930s, radical African political activists like Bankole Awooner-Renner and Isaac Theophilus Akunna (I.T.A.) Wallace-Johnson sought to organize workers 
into unions as part of a broader political project of anti-colonial resistance. ${ }^{36}$ As the historian Denzer notes, "For a radical journalist and trade unionist, Accra in the I930s was perhaps the most dynamic place in West Africa for political debate." ${ }^{37}$ Wallace-Johnson joined other activists including J.B. Danquah and Nnamdi Azikiwe in the Gold Coast to form the West African Youth League (WAYL) in 1935. Both within and outside the confines of the WAYL, Wallace-Johnson and others worked to organize African workers from a number of different sectors (including drivers) into unions, which he believed would mobilize Africans against colonial rule and raise awareness about social, political, and economic rights among the African public. ${ }^{38}$

Awooner-Renner and Wallace-Johnson drew on Marxist and Leninist ideas from the Soviet Union and European labor movements, as well as earlier labor movements within the continent itself. In the Gold Coast, the first miners' strike occurred in I919, and a number of labor unions the Gold and Silver Smiths' Association, the Gold Coast and Ashanti Motor Union, and the Carpenters' and Masons' Union - all formed in the I920s. The La Drivers' Union itself emerged in I 935 in response to these efforts at labor organization, drawing together drivers in the heart of the motor transport industry. However, the La Drivers' Union and other motor unions, like many other early labor organizations that formed in the first decades of the twentieth century, did not fit comfortably within conventional definitions of labor unions promoted by British trade unionists working within the colonial government.

Concerned about the strikes by railway workers and other types of labor unrest across the continent in the I930s and pressured by a metropolitan Labour Party government, British colonial officials in the Gold Coast and elsewhere brought in trade unionists to train workers in union organization. ${ }^{39}$ Government officials in Britain and the Gold Coast argued that the labor unrest was the result of lack of organization and training among early unions in the art of collective bargaining, which lay at the foundation of British trade unionism. ${ }^{4}$ Eager to curb strikes that were crippling the colonial economy, trade unionists arranged "education" sessions for African union officials and sponsored representatives of the largest unions to travel to Britain for more advanced training. ${ }^{4 \mathrm{I}}$

36. LaRay Denzer, "Wallace-Johnson and the Sierra Leone Labor Crisis of 1939", African Studies Review, 25:2/3 (1982), pp. I59-183, I62.

37. Ibid., p. 165.

38. Leo Spitzer and LaRay Denzer, "I.T.A. Wallace-Johnson and the West African Youth League", International Journal of African Historical Studies, 6 (1973), pp. 4I 3-452.

39. R.B. Davison, "Labor Relations in Ghana", p. I35.

40. Ibid.

4I. Ibid.; PRAAD-NAG (Accra) CSO I4/I/7I I 1940-1946 Courses of Instruction in Labour Problems. 
In order to facilitate collective bargaining and to maintain some control over emerging workers' organizations, colonial officials encouraged the centralization of smaller unions into larger umbrella structures, which were then registered with the government beginning in the early I940s. Such efforts were geared toward limiting the influence of the radical politics of people like Awooner-Renner and Wallace-Johnson. The formal recognition and registration of trade unions also enabled colonial officials better to control and influence the politics of labor organization in the colony. Colonial officials would negotiate only with those unions officially registered with the government, making it difficult for new unions to influence negotiations and enabling the colonial state to marginalize more radical unions in the bargaining process. ${ }^{42}$ Entrepreneurial drivers, who directly experienced the consequences of government reforms and regulations, constituted two of the first four unions to register with the government. ${ }^{43}$

Much of the collective bargaining and union organizing of workers in the colonial economy involved the state directly. Colonial capitalism, which centralized economic authority and wealth, privileged the state as the primary source of both jobs and capital. ${ }^{44}$ For state employees, like railway workers, collective bargaining over wages, benefits, and working conditions required negotiations with colonial officials. Drivers, by contrast, represented a very different kind of worker in the colonial capitalist economy. As self-employed entrepreneurs, drivers were not "employees" and received neither wages nor benefits directly from the colonial state. However, state actions often produced dramatic changes in the working conditions and profit margins of drivers. As the first real attempt to regulate driver practice, the 1934 Motor Traffic Ordinance marked one of the earliest examples of this relationship, mobilizing drivers across the country to protest government regulations that would redefine "the type of man who could be a driver". ${ }^{45}$

\section{UNIONS AT WORK}

In organizing themselves against the state, drivers drew on indigenous understandings of economic regulation and labor organization. As entrepreneurs, drivers operated on a basic assumption that the authorities should provide the appropriate conditions under which their businesses might grow and thrive - an assumption rooted in pre-colonial systems of

42. PRAAD-NAG (Accra) CSO I $4 / \mathrm{I} / 789$ I 943 The Bekwai Motor Transport Union.

43. PRAAD-NAG (Accra) CSO 25/3/1 32 1942-1946 Trade Unions - Registration of.

44. Davison, "Labor Relations in Ghana", p. 133.

45. PRAAD-NAG (Accra) CSO I 5/7/13 1939 Moses Acquaye - Motor driver request for restoration of his driving licence. 
political and social organization. For motor transportation, such conditions most obviously included roads - the construction and maintenance of which were necessary in order to reach customers in rural farming communities and markets. Good quality roads also minimized wear on vehicles, necessitating fewer repairs, and allowing a driver to use a vehicle for a longer period of time. The necessary conditions for their work also included inputs like petrol, tires, and spare parts. Drivers relied on subsidized costs for such inputs in order to keep fares low and compete in the transport market. In this sense, the rationale of the drivers was similar to that of other indigenous entrepreneurs: Drivers anticipated that the colonial government would guarantee the basic infrastructure of their work and enable them to secure preferential access to basic resources in the larger service of the public as well as of their own profit. Also, much like other indigenous entrepreneurs, drivers expected significant autonomy on the road itself, regulating their own training and practices to maximize profits and services.

For drivers, unions provided an opportunity not to engage in collective bargaining with the state but rather to pressure the state to limit the regulation of drivers and maintain their focus on what drivers considered a right to basic infrastructure and resources. Particularly in the aftermath of the 1934 Motor Traffic Ordinance, drivers' unions became mouthpieces for complaints about the new regulations and their impact on driver autonomy. Having been officially recognized by the state, many of these unions had the ear of colonial officials, who were obligated to consider and respond to union concerns. Both registered and unregistered motor transport unions engaged in petition-writing campaigns to the colonial Governor, Arnold Hodson. Drivers' protests focused primarily on new literacy requirements that were central to the new physical, social, and intellectual characteristics of "competency" introduced by the I934 Motor Traffic Ordinance.

According to Chief Transport Officer Cruickshank, the examinations by which applications for Certificates of Competency were evaluated were "held with a view to make sure that the applicants are familiar with the control of a Motor Vehicle and also that they know the Road Signs. This will eventually reduce the number of serious accidents on the roads where many passengers are injured." ${ }^{66}$ In practice, however, the new literacy requirements significantly redefined the accessibility of driving as a profession. Before 1934, the skills of drivers were defined by their ability to handle a vehicle. ${ }^{47}$ This new literacy requirement - and the

46. PRAAD-NAG (Accra) CSO i 5/7/i 8 I 934 Adjei Badoo, Motor driver - Complaint against ETO Mr (Cruickshank).

47. PRAAD-NAG (Accra) CSO i 5/7/7 1930 Tetteh Amartey, Motor driver - Complaint against confiscation of his driving licence and ios fee paid to licensing officer. 
broader conversations about competency of which they were a part reflected an expansion in the understanding of what it meant to be a driver, as well as the state's attempts to control driver practice.

The experiences of drivers themselves directly challenged the clarity and appropriateness of the new requirements. While drivers had long been required to have knowledge of road signs, many of those licensed before I 934 were classified as "illiterate". The new ordinance stipulated that any driver who had obtained his license before the 1934 Ordinance was enacted was exempt from the literacy requirement. The continuing operation of old, illiterate drivers alongside the more recently licensed literate drivers provided a direct challenge to colonial justifications of the literacy requirement. As the Ashanti Motor Union argued, "many of our best drivers are illiterate". ${ }^{8}$ In petitioning Governor Hodson, drivers protested what they viewed as a government that was overstepping its rights to regulate driver practice and implementing laws that did not reflect the interests of either drivers or passengers. However, drivers' petitions did not result in any fundamental changes to colonial regulation. Rather, the 1934 Motor Traffic Ordinance was only the first of a series of government efforts to regulate, rationalize, and restrict drivers' practices in an attempt to define African spatial realities and mobility both within and outside the colony's major cities.

Out of frustration, drivers in Accra finally went on strike in 1938. Chief among their complaints was the inadequate provision of lorry parks, which reflected neither the extent of the driver population in the city nor the ways in which people in Accra used lorries. ${ }^{49}$ The mobility made possible by motor transportation resulted in increasing numbers of traders bringing goods to sell in the large markets of major urban centers such as Accra. ${ }^{50}$ These traders and the mammy trucks/wagons that bore them overwhelmed existing lorry parks, forcing drivers to park illegally in the streets surrounding the city's major market. ${ }^{5 \mathrm{I}}$ Furthermore, alternative

48. PRAAD-NAG (Accra) CSO I7/I/39 1935-1938 Ashanti Motor Transport Union, "Petition from Motor Transport Union Ashanti (W.W. Taylor, Secretary) to the Chief Commissioner of Ashanti, November 29th, 1937". See also PRAAD-NAG (Accra) CSO i 5/7/8 I $1939 \mathrm{Mr}$ Kofi Baah - Petition praying for grant of Gold Coast driving license: "I have seen on many occasions that there are some lorry drivers who does not know how to read and write but are Drivers." For other petitions from unions concerning the 1934 Motor Traffic Ordinance and its subsequent amendments, see CSO i 5/7/99 1938 Motor Traffic Regulations - Amendments to; CSO I7/I/I 3 1934 Regulations under the Motor Traffic Ordinance; CSO 17/I/24 1935-1937 Motor Traffic Ordinance and Regulationsi934 - Petitions against.

49. PRAAD-NAG (Accra) CSO I4/I/270 1938-1939 Lorry parks, Accra.

50. This period also resulted in a noted shift in the gendered distribution of trading - from men to women, as men increasingly pursued wage labor work and cash-crop farming that had increased throughout the I9IOs and I920s.

5I. PRAAD-NAG (Accra) CSO i4/1/270 1938-1939 Lorry parks, Accra; PRAAD-NAG (Accra) CSO 17/4/6 1940-194I Native Administration - Lorry parks. 
markets such as London Market and Salaga Meat Market developed in various parts of the expanding city, and traders in these new markets demanded motor transport to carry their goods. ${ }^{52}$ The colonial government quickly responded to the striking motor drivers' demands - seeking out land for new lorry parks and expanding existing lorry parks.

Early strikes were considered troublesome because of their economic impact - a clear indicator of the degree to which the colony had become reliant on motor transportation to facilitate movement both between and within rural and urban areas. The success of the strikes required a strong network of social support from passengers and the broader community. Social sanction of driver protests was rooted in their identification as representatives of working-class African communities as well as the role that motor transportation played in facilitating the growth and prosperity of local economies in both rural and urban areas. In large part, the identification of drivers with the broad base of working-class Africans and indigenous entrepreneurs in the Gold Coast reflected the degree to which unionized drivers also continued to participate in indigenous cultures of work.

However, some unions appealed more directly to local understandings of labor organization and authority. Unions in La and Teshie appropriated the symbols of chieftaincy, and the social and political legitimacy that such symbols implied, to highlight the public responsibilities of drivers and the importance of their role in local communities. The head of the union was known as the "Chief Driver". Chief Drivers were confirmed in their office through a public ceremony, in which the La Manche (chief) (and sometimes even also the Ga Manche or Ga paramount chief), colonial government officials (such as the District Commissioner of Accra), and the larger La community gathered at union offices to witness the new Chief Driver swearing an oath on a steering wheel. ${ }^{53}$ This very public investiture emphasized the responsibility that drivers - and in particular the Chief Driver - had in protecting and ensuring the safety and interests of the larger community. ${ }^{54}$ Chief Drivers also appropriated the material culture of chieftaincy, appearing in photos wearing leopard-print hats, carrying fly whisks, and speaking through a "linguist", who represented

52. PRAAD-NAG (Accra) CSO I4/1/270 1938-1939 Lorry parks, Accra; PRAAD-NAG (Accra) CSO I4/I/27I 1938-I939 Land at Salaga Market Required for a Lorry Park Ownership of.

53. For more information about Ga governance structures and traditional offices, see John Parker, Making the Town: Ga State and Society in Early Colonial Accra (Portsmouth, NH, 2000).

54. Gene Quarshie (Chairman), P. Ashai Ollennu (Vice-Chairman), and Simon Djetey Abe (Secretary), La Drivers' Union Officers Group, La, Accra, 23 March 2009, interview by the author. 


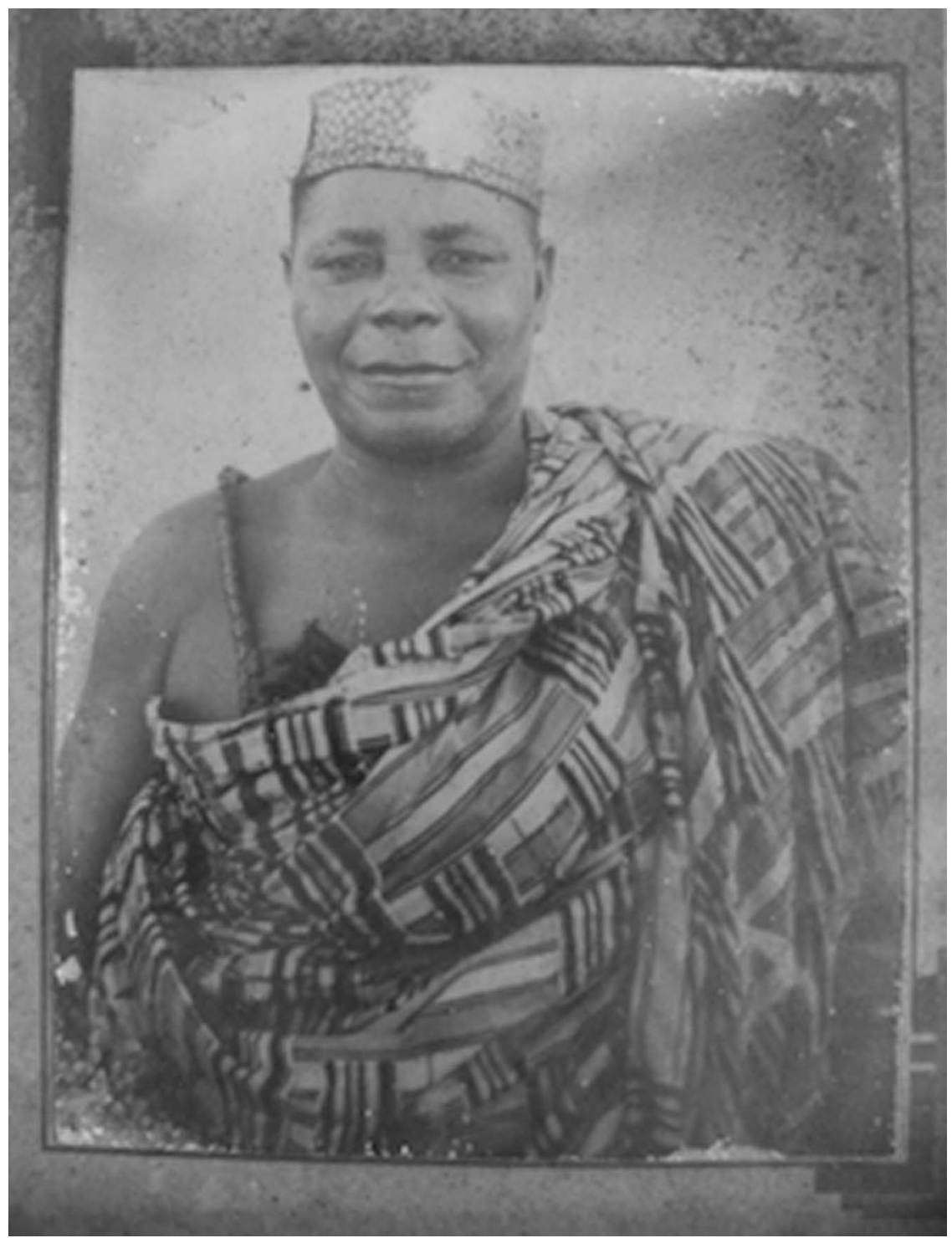

Figure 3. Here the first Chief Driver of Teshie was photographed in the mid-1930s wearing kente cloth and a leopard-print hat, both symbols of chieftaincy widely recognized throughout the Gold Coast. Although the Teshie union has since been absorbed into the national Ghana Private Road Transport Union, the photograph is prominently displayed in the Teshie branch office, Accra, Ghana.

Photographed by the author, 2009. Original photograph, property of the Teshie Branch of the Ghana Private Road Transport Union (GPRTU). 
the Chief Driver in public appearances and carried his own linguist's staff at public ceremonies, topped with a wooden image of a mammy truck to represent the "clan" of the drivers."

The structure of the La Drivers' Union drew directly from the structure of chieftaincy, which, as a British-invented tradition among Ga communities, had characterized political organization in La and greater Accra since at least the mid-nineteenth century. ${ }^{56} \mathrm{By}$ appropriating and mobilizing the language and symbols of chieftaincy, motor transport unions in La and Teshie explicitly allied themselves with the people - establishing themselves as the guardians and protectors of the community and their interests. Colonial state regulations of motor transportation that were enacted in what colonial officials understood as the "public interest" failed to grasp not only how drivers were trained and ran their businesses but also what kind of services the public valued. However, the appropriation of the material and symbolic culture of chieftaincy was only the most superficial and visible example of a much broader connection between drivers and local economic and cultural practice. As is clear in the 1938 strike, in organizing themselves into unions and protesting these state regulations, motor transport drivers acted to protect not only their interests but also, perhaps more indirectly, the economic interests and values of their passengers and the broader "culture of work" of which they were a part.

\section{CONCLUSION}

In appropriating and adapting trade union structures and practices to reflect indigenous cultures of work, drivers participated in a widespread phenomenon of African trade unionism, which simultaneously bound workers to the state while providing opportunities and foundations for worker resistance to state control. African workers adopted trade-union models in an attempt to counterbalance the power of a centralizing, extractive colonial state that sat at the core of the colonial economy. The characteristics of this colonial economy - the extractive and centralizing nature of colonial capitalism - from the start distinguished Africans' experiences from their trade-union colleagues in Britain. In encouraging the growth of unions, British colonial officials sought "to create, if not people, then societies in their own image"; however, they failed to

55. Ibid.; Abraham Tagoe, Teshie Linguist, Accra, 5 August 2009, interview by the author. 56. For further information about chieftaincy and the okyeame, see Kwesi Yankah, Speaking for the Chief: Okyeame and the Politics of Akan Royal Oratory (Bloomington, IN, I995); Steven J. Salm and Toyin Falola, Culture and Customs of Ghana (Westport, CT, 2002); Irene K. Odotei and Albert K. Awedoba (eds), Chieftaincy in Ghana: Culture, Governance and Development (Accra, 2006). For discussions of chieftaincy outside Akan communities, see Paul Stacey, Traditional Uncertainty; Chieftaincy in Northern Ghana: Land Control and Ethnic Conflicts, I90I-I996 (Saarbrücken, 2009); Parker, Making the Town. 
recognize the extent to which both the foundations of colonial capitalism and the values and practices of indigenous economies differed from metropolitan models. ${ }^{57}$ Rather, colonial officials introduced unions in the hope that they would limit strikes and bring workers under the control of the state, by encouraging collective bargaining. In practice, however, the unionization of African workers from various sectors legitimated worker protest and forced the state to reckon with the realities of life for African workers or face resistance.

At the same time, drivers are distinguished from the unionized African workers that have most commonly captured the attention of Africanist scholars. Unlike railway workers and dockworkers, who were often in the direct employ of the colonial state, drivers were self-employed entrepreneurs. Autonomy and entrepreneurialism enabled drivers to craft a culture and practice of unionism and work distinct from British colonial expectations and models. In fact, their work, which made possible new forms of mobility and economic prosperity among Ghanaians in both rural and urban areas, undermined the very assumptions about African inferiority and the necessity of European assistance on which British colonial rule in the Gold Coast was founded and reasserted African control over economic activities.

While it is tempting to see drivers' unions as proto-nationalist organizations, drivers and union leaders did not see their actions as explicitly political, and they did not participate in the nationalist mobilizations of railway workers' unions, for example, in the decades leading up to independence. Individual drivers, of course, could participate in politics, and many did. But drivers' unions were not structures of political mobilization in the early nationalist movement. These choices by union leaders to remain "above the fray" likely reflected the degree to which they believed that, as entrepreneurs who required preferential access to resources in order to remain profitable, their relationship with the state must be productive. This implies some sort of co-optation of union leaders into the structures of state governance. However, their unwillingness to engage in political resistance and nationalist organizing should not detract from the very real implications of their actions for the logics and practices of colonial governance. The entrepreneurialism and autonomy of drivers, their importance to the colonial economy, and the social sanction of their actions provided a powerful check on the colonial state's efforts to remake African economies in the Gold Coast and ignore indigenous economic priorities and practices. ${ }^{58}$

57. Davison, "Labor Relations in Ghana", p. I35.

58. I argue elsewhere that these actions represent citizenship claims in the context of colonial rule, rather than resistance - demands for belonging and protection rather than calls to revolution. See Jennifer Hart, "Suffer to Gain: Citizenship, Accumulation, and Motor Transportation in Late-Colonial and Postcolonial Ghana" (Ph.D., Indiana University, 20I I). 
The unionization of drivers, and the particular union cultures that derived from their organization and registration with the state, highlighted the degree to which drivers very much saw themselves as entrepreneurs defined by their autonomy and control over systems of training and regulation. While they operated within a broad framework of state infrastructure and expected access to subsidized resources, drivers used formally recognized unions to protect their autonomy and economic prosperity in the face of efforts at state regulation and control. The logics and motivations of driver action and the relative success of their petitions and protests were profoundly shaped by indigenous economic values and practices of apprenticeship, entrepreneurialism, and the state/chieftaincy. Much like the union model, drivers also adapted these forms of indigenous economy to better fit the realities of the emerging mobility system of motor transportation. As a result, perhaps even more than their peers in other waged labor occupations, the experiences of drivers suggest that the development and success of trade unions in the Gold Coast reflected not merely an adaptation of an imported metropolitan model, but rather the negotiation of diverse forms of African labor organization. 